\title{
Rekwizycje na ziemiach polskich w latach 1919-1920 w świetle ustawodawstwa i orzecznictwa sądowego
}

\author{
Requisitions on Polish Soil in 1919-1920 in the light of the legislation \\ and judicial decisions \\ Реквизиции на польской территории в 1919-1920 годах в свете законодательства \\ и судебной практики
}

\author{
MARCIN KONARSKI \\ Dr, Wyższa Szkoła Menedżerska w Warszawie \\ e-mail: marcin.konarski@wsm.warszawa.pl, https://orcid.org/0000-0001-8791-884X
}

\begin{abstract}
Streszczenie: Będąca przedmiotem niniejszej analizy instytucja rekwizycji przynależy do materii związanych z obowiązkiem ponoszenia świadczeń rzeczowych przez ludność znajdującą się na obszarze działań zbrojnych, stanowiąc pole zainteresowania przede wszystkim nauki prawa międzynarodowego publicznego i prawa administracyjnego. Instytucja rekwizycji wojennej, rozumianej jako sposób pozyskiwania na potrzeby zaopatrzenia wojsk istotnych z jego punktu widzenia przedmiotów, posiada wielowiekową tradycję i pozostaje związana z działaniami wojennymi prowadzonymi na przestrzeni wieków przez poszczególne narody i państwa. Celem artykułu jest analiza zagadnień normatywnych związanych ze stosowaniem tej instytucji przez wojsko polskie w okresie wojny polsko-bolszewickiej 1920 r., w świetle ówczesnego ustawodawstwa regulującego tę materię oraz orzecznictwa sądów polskich w tym zakresie po zakończeniu działań wojennych.
\end{abstract}

Słowa kluczowe: II Rzeczpospolita, prawo administracyjne, świadczenia wojenne, prawo wojenne, rekwizycje, rozkaz wojskowy, sądownictwo administracyjne

Summary: The institution of requisitioning, analysed in this article, belongs to the area of research related to the obligation to provide in-kind contributions by the population in the area of military operations. It is primarily an area of interest for the study of international public law and administrative law. The institution of war requisitioning, understood as a way of obtaining items important for the supply of troops, has a centuries-long tradition and is connected with warfare carried out by individual nations and States over the centuries. The aim of the article is to analyse normative issues related to the use of this institution by the Polish army during the Polish-Bolshevik War of 1920, in light of the legislation regulating on this matter at that time and decisions of Polish courts in this area after the end of warfare.

Key words: Second Polish Republic, administrative law, wartime duties, law of war, requisitioning, military command, administrative courts

\begin{abstract}
Резюме: Институт реквизиции, который является предметом настоящего анализа, относится к вопросам, связанным с обязанностью несения материальных благ населением, находящимся в зоне военных действий, является сферой интересов науки в рамках международного публичного права и административного права. Институт военной реквизиции, понимаемый как способ приобретения важных с его точки зрения объектов для нужд снабжения армий, имеет многовековую традицию и остается связанным с военными операциями, проводимыми на протяжении веков различными народами и государствами. Целью настоящей статьи является анализ нормативных вопросов, связанных с использованием этого института польской армией во время польско-большевистской войны 1920 года, в свете законодательства, регулирующего этот вопрос в то время, и судебной практики польских судов в этой области после окончания военных действий.
\end{abstract}

Ключевые слова: Вторая Польская Республика, административное право, военные платежи, военное право, реквизиции, военный приказ, административная судебная система 


\section{Wstęp}

Zagadnienia stanowiące przedmiot niniejszej analizy znajdują się w zakresie zainteresowania wielu gałęzi prawa, zarówno więc nauki prawa międzynarodowego publicznego, jak i prawa konstytucyjnego oraz prawa administracyjnego materialnego. Wynika to $\mathrm{z}$ faktu, że instytucja rekwizycji posiada charakter wielopłaszczyznowy i wielowymiarowy (interdyscyplinarny) przez wzgląd na swoją naturę i przedmiot, który z pewnością stanowi dla badacza norm prawnych niezwykle interesujący obszar dociekań naukowych. We wszystkich przywołanych gałęziach prawa instytucja rekwizycji przynależy do materii łączących się z obowiązkiem ponoszenia świadczeń rzeczowych i osobistych. W przypadku prawa międzynarodowego publicznego pozostaje związana ze stanem wojny, w którym stosowane są środki przymusu ${ }^{1}$, i władzą nieprzyjaciela w zajętym kraju² oraz instytucją konieczności wojskowej (military necessity), na której wyłącznie się opiera ${ }^{3}$. W przypadku zaś prawa krajowego - prawa konstytucyjnego i administracyjnego, zagadnienia te powiązane są z realizacją konstytucyjnego obowiązku obrony Ojczyzny oraz obowiązku ponoszenia ciężarów i świadczeń przez ludność państwa

1 Zob. H. Dembiński, Wojna jako narzędzie prawa i przewrotu, Lublin 1936, s. 39-58; K. Skubiszewski, Prawo wojny i neutralności w świecie współczesnym, Ruch Prawniczy, Ekonomiczny i Socjologiczny 1967, t. 29, z. 1, s. 105-125; C. von Clausewitz, On War, tłum. J.J. Graham, Ware 1997, s. 5-24; M. Konarski, Godność osoby ludzkiej a wojna lądowa w świetle prawa międzynarodowego, w: Normatywny wymiar godności człowieka, red. W. Lis, A. Balicki, Lublin 2012, s. 287-288.

2 Zresztą sytuacja prawna terytorium pozostającego pod okupacją wojenną stwarza w praktyce wiele skomplikowanych kwestii prawnych, które po zakończeniu działań militarnych były nieraz przedmiotem orzecznictwa sądowego, zob. S. Rundstein, Szkody wojenne. Teoria nadzwyczajnych indemnizacji w prawie publicznym, Warszawa 1916, s. 37. Szerzej na temat rekwizycji mienia na terytoriach okupowanych zob. I. Dinstein, The International Law of Belligerent Occupation, Cambridge 2019, s. 228-256. Podkreślmy w tym miejscu, że niniejsza analiza, przez wzgląd na przyjęty zakres badań, nie odnosi się do działań rekwizycyjnych władz okupacyjnych, lecz własnej armii. Niemniej należy zauważyć, że w poddanym analizie okresie obowiązywała już IV Konwencja haska dotycząca praw i zwyczajów wojny lądowej z 1907 r., gdzie w załączonym do niej Regulaminie znajdują się postanowienia dotyczące rekwizycji (art. 52-53), przy czym pamiętać trzeba, że postanowienia tej Konwencji zaczęły obowiązywać Polskę dopiero od 9 lipca 1925 r., zob. Oświadczenie Rządowe z dnia 20 stycznia 1927 r. w sprawie przystąpienia Rzeczypospolitej Polskiej do Międzynarodowej Konwencji, dotyczącej praw i zwyczajów wojny lądowej, podpisanej wraz z odnośnym regulaminem w Hadze dnia 18 października 1907 roku, Dz. U. z 1927 r. Nr 21, poz. 160; Konwencja dotycząca praw i zwyczajów wojny lądowej, Dz. U. z 1927 r. Nr 21, poz. 161.

3 Zob. Z. Cybichowski, Międzynarodowe prawo wojenne, Lwów 1914, s. 72-81; J.E. Makowski, Prawo międzynarodowe, Warszawa-Lublin 1918, s. 520; R. Bierzanek, Wojna a prawo międzynarodowe, Warszawa 1982, s. 54-62; E. Jaworski, „Military Necessity” and "Civilian Immunity”: Where is the Balance, Chinese Journal of International Law 2003, t. 2, nr 1, s. 175-206; M. Byers, War Law. Understanding International Law and Armed Conflict, New York 2005, s. 115-126; D. Luban, Military Necessity and the Cultures of Military Law, Leiden Journal of International Law 2013, t. 26, nr 2, s. 315-349. 
(obywateli) $)^{4}$ Wraz z ewolucją tych obciążeń i wraz z kształtowaniem się nowożytnych form ustrojowych państwa ciężary i świadczenia te zostały zaadaptowane w drodze zwyczajowej do potrzeb współczesnego państwa (powinność drogowa, powinność podwodowa, powinność kwaterunku wojskowego, podatki pożytku miejscowego, podatki bezpośrednie wobec samorządu itp. $)^{5}$. Ostatecznie więc w doktrynie prawa konstytucyjnego i administracyjnego ${ }^{6}$ przyjmuje się, że ciężary (powinności) publiczne to obowiązki nakładane na jednostki, będące świadczeniami czegoś na rzecz administracji publicznej Taki też sposób ich rozumienia został przyjęty na potrzeby niniejszego studium.

Nim przejdziemy do dalszych, szczegółowych rozważań, należy wpierw dokonać rozbioru zakresu znaczeniowego instytucji rekwizycji, jej charakteru prawnego i granic uprawnienia do jej przeprowadzania.

Instytucja rekwizycji wojennej, rozumianej jako sposób pozyskiwania na potrzeby zaopatrzenia wojsk istotnych $\mathrm{z}$ jego punktu widzenia przedmiotów, istnieje w formie „prawa łupu” zapewne od czasów ${ }^{8}$, kiedy ludzie zaczęli prowadzić ze sobą pierwsze walki ${ }^{9}$ jednak wraz z postępem cywilizacyjnym i rozwojem sztuki wojennej ewoluowała do czasów nam współczesnych.

Brak żołdu, niedochodzącego na czas, zmuszał żołnierzy do rekwizycji żywności i paszy dla koni, co pociągało rzecz jasna niemałe straty gospodarcze u ludności,

4 Por. A. Huchla, Ciężary i świadczenia publiczne a podatki w świetle art. 84 Konstytucji Rzeczypospolitej Polskiej, w: Konstytucyjne uwarunkowania tworzenia i stosowania prawa finansowego i podatkowego, red. P.J. Lewkowicz, J. Stankiewicz, Białystok 2010, s. 141-146; M. Szalewska, Ciężary i świadczenia publiczne, w: System Prawa Administracyjnego, t. 7. Prawo administracyjne materialne, red. R. Hauser, Z. Niewiadomski, A. Wróbel, Warszawa 2012, s. 525-526.

5 Zob. H. Konic, Samorząd gminny w Królestwie Polskiem w porównaniu z innemi krajami europejskiemi, Warszawa 1906, s. 177-189. Na temat źródeł tych ciężarów w czasach nowożytnych zob. W. Grabski, Ciężary samorządu w Królestwie Polskim, Warszawa 1908, s. 5-8; M. Konarski, Przyczynek do badań nad publicznymi postugami transportowymi i komunikacyjnymi w dawnym prawie polskim, Studia Prawnicze KUL 2019, nr 3, s. 111-131; tenże, Powinności podwodowe w świetle przekazu pierwszych sześciu tomów „Volumina Legum”, Biuletyn Stowarzyszenia Absolwentów i Przyjaciół Wydziału Prawa Katolickiego Uniwersytetu Lubelskiego 2019, t. 14, nr 2, s. 63-64.

6 Por. Z. Cybichowski, Polskie prawo państwowe na tle uwag z dziedziny nauki o państwie i porównawczego prawa państwowego, t. 3, Warszawa 1933, s. 31-32.

7 Zob. S. Kasznica, Polskie prawo administracyjne. Pojęcia i instytucje zasadnicze, Poznań 1946, s. 124.

$8 \mathrm{Na}$ temat relacji własności publicznej i prawa łupu zob. R. Bierzanek, Wojna a prawo..., s. 256-262. Por. Wojenna zdobycz, Dziennik Rozkazów Wojskowych Ministerstwa Spraw Wojskowych (dalej: DRMSW) Nr 93, poz. 2952; rozkaz Dowództwa Okręgu Korpusu (dalej: RDOKK) Nr 8 (Kielce), Nr 76 z dnia 24 września 1920 r., poz. 21-24, s. 5-8; K. Łopatecki, Zawłaszczenie nieruchomości na przykładzie działań wojennych z poczq̨tku XVII wieku w Rzeczypospolitej Obojga Narodów. Z badań nad prawem zdobyczy wojennej w epoce nowożytnej, Zeszyty Prawnicze 2016, t. 16, nr 4, s. 59-88.

9 Por. F. Smolka, Ptolemejska ustawa kwaterunkowa, Archiwum Towarzystwa Naukowego we Lwowie. Wydział 2, Historyczno-Filozoficzny 1935, t. 16, z. 3, s. 335. 
głównie w inwentarzu żywym ${ }^{10}$. Jak pisze A. Czekaj, „żywienie żołnierzy kosztem społeczeństwa jako rozbudowany proceder narodziło się na zachodzie Europy w czasie wojny trzydziestoletniej. System kontrybucji i rekwizycji do perfekcji doprowadził sam Albrecht Wallenstein. Praktycznie każdy z dowódców starał się na własną rękę wycisnąć z ludności tyle, ile się dało. Dowódcy polscy, przeciwnie starali się zawsze, w miarę swoich możliwości, uchronić ludność miejscową przed skutkami występków żołnierskich, posuwając się nawet niejednokrotnie do płacenia podległym chorągwiom $\mathrm{z}$ własnej kieszeni, żeby poprawić ich byt, a tym samym zmniejszyć skłonność do rabunków"11.

W okresie Księstwa Warszawskiego, czy wcześniej w dobie wojen rewolucyjnej Francji, a następnie wojen napoleońskich zaspokajanie potrzeb wojska ${ }^{12}$ często odbywało się w drodze przeprowadzanych rekwizycji ${ }^{13}$, których częstym skutkiem,

10 Por. T. Srogosz, Ekonomiczne i społeczne następstwa przemarszów oraz stacjonowania wojsk własnych na terenie województw tęczyckiego i sieradzkiego oraz ziemi wieluńskiej w XVII wieku, Acta Universitatis Lodziensis. Folia Historica 1990, t. 37, s. 3-33.

11 A. Czekaj, Obywatele czy kondotierzy? Postawy obywatelskie i moralne żotnierzy narodowego autoramentu wojsk Rzeczypospolitej w pierwszej połowie XVII wieku, w: Staropolska sztuka wojenna XVI-XVII wieku. Prace ofiarowane Profesorowi Jaremie Maciszewskiemu, red. I.M. Dacka-Górzyńska, A. Karpiński, M. Nagielski, Warszawa 2002, s. 94-95. Tytułem porównania przypomnijmy, że traktat zawarty w 241 r. p.n.e. po kapitulacji Kartaginy stanowił, że Kartagińczycy mają zapłacić Rzymowi dziesięć tysięcy talentów srebra tytułem kontrybucji w równych ratach rocznych w ciągu 50 lat, zob. M.N. Faszcza, Kulturowe implikacje rzymskiej deditio w III-I wieku przed Chrystusem, w: Kapitulacje $w$ dziejach wojen. $Z$ dziejów wojskowości polskiej i powszechnej, red. A. Niewiński, Oświęcim 2017, s. 21. Z kolei w okresie „potopu” szwedzkiego Karol X Gustaw, wkroczywszy do Warszawy, obłożył ludność podatkiem wojennym - co miało miejsce również na innych obszarach - którego wysokość każdorazowo zależała od liczby mieszkańców okupowanego miasta oraz ilości domów. Szerzej na temat rejestrów kontrybucji w okresie „potopu” szwedzkiego zob. K. Wagner, „Potop” a wielka wojna pótnocna $w$ Warszawie $w$ świetle rejestrów podatkowych - przyczynek do porównania dwóch szwedzkich okupacji, Saeculum Christianum 2013, t. 20, s. 109-119.

12 Mowa tutaj przede wszystkim o obowiązku kwaterunkowym, obowiązku dostarczania podwód dla wojska oraz żywności i furażu, zob. Z. Filipiak, Kwaterunek wojskowy w domach prywatnych Księstwa Warszawskiego. Regulacje prawne, Studia Iuridica Toruniensia 2011, t. 9, s. 215-229; M. Konarski, Publiczne posługi transportowe w okresie Księstwa Warszawskiego w świetle postanowień dekretu $z$ dnia 22 maja 1810 roku „względem koni i podwód dostarczonych pod transporty i wojskowych”, Czasopismo Prawno-Historyczne 2019, nr 2, s. 113-135 i przywołaną tam literaturę oraz źródła archiwalne; tenże, Legal Aspects of Organising the Administration of Food for the Army in the Duchy of Warsaw between 1807 and 1812, Biuletyn Stowarzyszenia Absolwentów i Przyjaciół Wydziału Prawa Katolickiego Uniwersytetu Lubelskiego 2020, t. 15, nr 1, s. 99-128 i przywołaną tam literaturę oraz źródła archiwalne.

13 Zob. Archiwum Główne Akt Dawnych (AGAD), Rada Stanu i Rada Ministrów Księstwa Warszawskiego, zespół nr 175, sygn. 202, k. 1-69; AGAD, Rada Ministrów Księstwa Warszawskiego, zespół nr 176, sygn. 117, k. 2-143. Por. M. Wise, Requisition During the French Revolution (1789-1815), Louisiana Law Review 1944, t. 6, nr 1, s. 47-62; J. Gilas, Położenie prawnomiędzynarodowe Powiśla, Warmii i Mazur w latach 1918-1920, Komunikaty Mazursko-Warmińskie 1970, nr 2, s. 232; 
podobnie jak w wiekach poprzednich, były liczne nadużycia związane z poborem żywności i furażu dla wojska oraz przechowywaniem tych produktów w magazynach ${ }^{14}$. Jeśli zaś idzie o odszkodowania za przeprowadzone rekwizycje, to zauważmy w tym miejscu jedynie, za S. Rundsteinem, że „dekrety z czasu pomiędzy r. 1805 a 1811 ustalają zasadę, że szkody, wynikające z kontrybucji i rekwizycji nieprzyjacielskich równomiernie podzielone być winny pomiędzy tymi, którzy je ponieśli a tymi, w których interesie zostały poniesione"15.

Nie sposób, przez wzgląd na ramy niniejszej analizy, odnieść się do wszystkich zagadnień związanych z kształtowaniem się od końca XVIII w. nowożytnej instytucji rekwizycji i problematyki odszkodowań za nie ${ }^{16}$. Podkreślić jednak trzeba, że „w XIX wieku - w związku z tendencją do ochrony własności prywatnej - przyjęła się praktyka rekwizycji, za którą wypłacano właścicielom kwoty mniej lub więcej odpowiadające wartości rekwirowanych przedmiotów. W ten sposób uległa złagodzeniu dawna zasada »wojna żywi wojnę«"17.

Wobec tego, co już zostało powiedziane, cel badawczy niniejszych rozważań będzie stanowiła analiza zagadnień normatywnych związanych ze stosowaniem instytucji rekwizycji przez wojsko polskie w okresie wojny polsko-bolszewickiej w 1920 r. w świetle ówczesnego ustawodawstwa regulującego tę materię oraz orzecznictwa sądów polskich w tym zakresie po zakończeniu działań wojennych. $\mathrm{Na}$ potrzeby analizy przyjęto najbardziej odpowiadającą jej metodę odkrycia

M. Przeniosło, Ziemiaństwo w Królestwie Polskim i jego straty poniesione w pierwszym roku Wielkiej Wojny, Dzieje Najnowsze 2004, nr 3, s. 95-112.

14 Szerzej zob. J. Przygodzki, Rekwizycje w Księstwie Warszawskim w okresie rosyjskich rząów okupacyjnych, Acta Universitatis Wratislaviensis. Prawo 2001, nr 273 s. 125-140. Na temat organizacji administracji żywności dla wojska i zagadnień związanych z dostarczaniem produktów do wspomnianych magazynów żywności w Księstwie Warszawskim zob. M. Konarski, Legal Aspects..., s. 99-128.

Zob. S. Rundstein, Szkody wojenne..., s. 155-156. Por. M. Lewy, Uwagi w kwestji szacowania wynagrodzenia za rekwizycje, dokonane przez Niemców w b. Królestwie Polskiem, Warszawa 1920, s. 1-16.

Szerzej zob. L. Domański, Przegląd przepisów prawnych, wydanych we Francji w związku z wojnq 1914-1915 roku (dokończenie), Gazeta Sądowa Warszawska 1915, nr 25 + dodatek, s. 313-316; S. Rundstein, Szkody wojenne..., s. 45-46, 60-61, 130-133, 155-156, 195, 261, 279; L. Babiński, Rejestracja i indemnizacja strat wojennych w świetle ustaw wydanych we Francji po r. 1814-15 i 1870-71, w Niemczech po r. 1870-71, w Austrji po r. 1866, w Rosji po r. 1904-5, w: Likwidacja skutków wojny $w$ dziedzinie stosunków prawnych i ekonomicznych $w$ Polsce, t. 2, Warszawa 1917, s. 14-15, 17-18, 22-30, 61-62, 76-80, 91; A. Kraushar, Sprawa likwidacji strat wojennych za Księstwa Warszawskiego (1807-15), w: Likwidacja skutków wojny..., t. 2, s. 101; N. Gąsiorowska, Rekwizycje w Księstwie Warszawskim okupowanym przez Rosję w roku 1813-15, w: Likwidacja skutków wojny..., t. 2, s. 105-127; J. Iwaszkiewicz, Rejestracja i indemnizacja strat wojennych na Litwie po roku 1812, w: Likwidacja skutków wojny ..., t. 2, s. 131, 141; J. Przygodzki, Rekwizycje w Księstwie Warszawskim..., 125-140.

R. Bierzanek, Wojna a prawo..., s. 248-249. 
naukowego ${ }^{18}$, a mianowicie metodę historyczno-prawną i dogmatyczno-prawną, jak również w ograniczonym zakresie metodę prawno-porównawczą ${ }^{19}$.

\section{Ustawodawstwo rekwizycyjne w pierwszych latach II Rzeczypospolitej}

Podstawę systemu świadczeń wojennych, w tym świadczeń rekwizycyjnych, dającą państwu za pośrednictwem upoważnionych organów prawo żądania od ludności tych świadczeń, a w szczególności odpłatnego odstępowania na rzecz państwa własności lub prawa użytkowania ruchomości i nieruchomości bezpośrednio lub pośrednio potrzebnych dla celów zaopatrzenia armii i obrony państwa, lecz wyłącznie dopiero z chwilą wybuchu wojny lub zarządzenia częściowej bądź ogólnej mobilizacji ${ }^{20}$, stanowiła uchwalona dnia 11 kwietnia 1919 r. ustawa o rzeczowych świadczeniach wojennych ${ }^{21}$. Ustawa obowiązywać miała prowizorycznie na okres jednego roku ${ }^{22}$, zaś z chwilą wejścia jej w życie utraciły moc prawną wszystkie inne ustawy i przepisy w przedmiocie rekwizycji i świadczeń wojennych, jednakże pod warunkiem, że chodziło o rekwizycje i świadczenia wojenne, które miały być zarządzone od chwili wejścia w życie ustawy.

18 Zob. K.R. Popper, Logika odkrycia naukowego, tłum. U. Niklas, Warszawa 1977, s. 29.

19 Zob. I. Łyskowski, O metodzie w badaniach prawno-historycznych, Ruch Prawniczy, Ekonomiczny i Socjologiczny 1929, t. 9, z. 1, s. 1-9; J. Bardach, Themis a Clio, czyli o potrzebie podejścia historycznego w prawoznawstwie, w: tenże, Themis a Clio, czyli prawo a historia, Warszawa 2001, s. 10-33; P. Dobosz, Problemy metodologii współczesnej nauki prawa administracyjnego na tle metody historyczno-prawnej, Kwartalnik Prawa Publicznego 2001, nr 1, s. 9-47. Por. J. Stelmach, B. Brożek, Metody prawnicze, Kraków 2006, s. 32-35.

20 Szerzej na temat systemów mobilizacyjnych zob. T. Zakrzewski, Organizowanie sity zbrojnej w państwie, Warszawa 1938, s. 89-90; C. Berman, Mobilizacja w teorii i praktyce, Warszawa 1964, s. 5-6; M. Koch, Wojskowa ekonomika zaopatrzenia materiałowo-technicznego, Warszawa 1980, s. 4-20; J. Orzechowski, Dowodzenie i sztaby. II wojna światowa i współczesność, Warszawa 1986, s. 91-94 i $203-205$.

21 Ustawa z dnia 11 kwietnia 1919 r. o rzeczowych świadczeniach wojennych, Dziennik Praw Państwa Polskiego (dalej: Dz. Pr. P. P.) z 1919 r. Nr 32, poz. 264. Rozporządzenie wprowadzające z dniem 1 maja 1919 r. obowiązek świadczeń wojennych ukazało się 29 kwietnia, zob. rozporządzenie Ministerstwa Spraw Wojskowych i Ministerstwa Spraw Wewnętrznych w sprawie wprowadzenia obowiązku świadczeń wojennych, M.P. z 1919 r. Nr 98.

22 Kiedy utraciła swoją moc, wydana została już 23 kwietnia 1920 r. ustawa przywracająca jej moc obowiązującą, zob. ustawa z dnia 23 kwietnia $1920 \mathrm{r}$. w przedmiocie przywrócenia mocy obowiązującej i częściowej zmiany ustawy z dnia 11 kwietnia 1919 r. o rzeczowych świadczeniach wojennych, Dz. U. z 1920 r. Nr 37, poz. 212. 
Wprowadzenie obowiązku świadczeń wojennych, ustanowienie terminu powstania i ustania rzeczowego obowiązku, jak również oznaczenie przedmiotów podlegających obowiązkowemu świadczeniu następowało na skutek wspólnego rozporządzenia Ministra Spraw Wojskowych i Ministra Spraw Wewnętrznych, które wydano dnia 29 kwietnia $1919 \mathrm{r}^{23}$ Zgodnie z postanowieniami zawartymi w rozporządzeniu obowiązek przymusowego świadczenia obejmował ruchomości (zwierzęta pociągowe i wszelkie środki transportowe, bez względu jaką siłą poruszane, wraz ze wszystkimi potrzebnymi do ich użytku przyborami, urządzeniami i zakładami) ${ }^{24}$, jak i nieruchomości (m.in. do celów kwaterunkowych) ${ }^{25}$.

Na podstawie wspomnianej ustawy z dnia 11 kwietnia 1919 r. przy Ministerstwie Spraw Wojskowych utworzony został Główny Urząd Zaopatrywania Armii $(\text { GUZA })^{26}$, do kompetencji którego należało m.in. ześrodkowywanie i pokrywanie ogólnego zapotrzebowania armii. Żądanie świadczeń wojennych następowało w drodze nakazów rekwizycyjnych, wydawanych przez właściwe urzędy administracyjne na podstawie zapotrzebowań wystawionych przez władze wojskowe, czyli do Ministra Spraw Wojskowych oraz do upoważnionych przez niego organów ${ }^{27}$.

23 Rozporządzenie Ministerstwa Spraw Wojskowych i Ministerstwa Spraw Wewnętrznych z dnia 29 kwietnia 1919 r. w sprawie wprowadzenia obowiązku świadczeń wojennych, M.P. z 1919 r. Nr 98.

24 W uzupełnieniu wydano następnie dwa rozporządzenia w dniu 1 listopada 1919 r., zob. rozporządzenie Ministra Spraw Wojskowych i Ministra Spraw Wewnętrznych w sprawie wprowadzenia obowiązku świadczeń wojennych (uzupełnienie rozporządzenia z dnia 29 kwietnia 1919 r. - M.P. Nr 98); rozporządzenie Ministra Spraw Wewnętrznych z dnia 1 listopada 1919 r. w sprawie składania deklaracji o posiadaniu przedmiotów, niezbędnych do zaopatrzenia armii w odzież, M.P. z 1919 r. Nr 246. Por. obwieszczenie Komisarza Rządu na m. st. Warszawę z dnia 13 lipca 1920 r. w sprawie składania deklaracji o posiadaniu przedmiotów niezbędnych dla zaopatrzenia armii w odzież, Dziennik Urzędowy Komisariatu Rządu na m. st. Warszawę z dnia 16 lipca 1920 r., Nr 14. Kolejne zarządzenie obowiązku przymusowego świadczenia wymienionych przedmiotów nastąpiło w dniu 22 marca $1920 \mathrm{r}$. w drodze rozporządzenia Ministra Spraw Wojskowych i Ministra Spraw Wewnętrznych w sprawie wprowadzenia obowiązku świadczeń wojennych, Dz. U. z 1920 r. Nr 30, poz. 177.

25 Zob. dekret w przedmiocie rekwizycji lokali na potrzeby urzędów państwowych, Dz. Pr. P. P. z 1919 r. Nr 14, poz. 197; ustawa z dnia 8 kwietnia 1919 r. o dostarczaniu mieszkań na potrzeby wojska, Dz. Pr. P. P. z 1919 r. Nr 31, poz. 262; ustawa z dnia 27 listopada 1919 r. o obowiązku zarządów gmin miejskich dostarczania pomieszczeń, Dz. U. z 1919 r. Nr 92, poz. 498; ustawa z dnia 23 kwietnia 1920 r. w przedmiocie przedłużenia mocy obowiązującej ustawy z dnia 3 kwietnia 1919 r. o dostarczaniu mieszkań na potrzeby wojska, Dz. U. z 1920 r. Nr 37, poz. 211; rozkaz Ministra Spraw Wojskowych z dnia 22 lutego 1920 r. w sprawie rekwizycji mebli zajętych przez sądy, DRMSW Nr 7 z dnia 9 marca 1920 r., poz. 147; rozkaz Ministra Spraw Wojskowych z dnia 10 kwietnia 1920 r. o kompetencjach przy rekwizycji na cele wojskowe pomieszczeń i zarządzenia nimi, DRMSW Nr 13 z dnia 27 kwietnia 1920 r., poz. 314.

26 Ustawa z dnia 11 kwietnia 1919 r. o utworzeniu Głównego Urzędu Zaopatrywania Armji, Dz. Pr. P. P. z 1919 r. Nr 32, poz. 265.

27 Pamiętać jednak należy, że wskutek działań wojennych Rada Obrony Państwa wydała rozporządzenie, $\mathrm{w}$ świetle postanowień którego w wypadku wojennego zagrożenia obszarów państwa Minister 
Co do wynagrodzeń za świadczenia wojenne, to ustawa o rzeczowych świadczeniach wojennych przewidywała, że regułą miało być bezzwłoczne wynagrodzenie w postaci gotówki, wypłacone po cenach ustalonych przez Ministerstwo Spraw Wojskowych w porozumieniu z Ministerstwem Skarbu i innymi zainteresowanymi przedmiotowo ministerstwami ${ }^{28}$, na podstawie opinii wydanej przez reprezentacje organizacji rolniczych, rękodzielniczych, handlowych i przemysłowych. W przypadku gdy zapłata nie była możliwa natychmiastowo, posiadacze przedmiotów świadczeń mieli otrzymać kwity rekwizycyjne ustalone według wzoru przez Ministerstwo Spraw Wojskowych ${ }^{29}$. Wypłatę należności z kwitów rekwizycyjnych dokonywać miała intendentura najbliższego wojskowego okręgu generalnego ${ }^{30}$. Natomiast $\mathrm{w}$ razie niedokonania zapłaty, nikt nie mógł być pociągnięty do spełnienia obowiązku świadczenia wojennego, jeżeli nie został mu wręczony kwit rekwizycyjny $^{31}$. Zgłoszenie kwitów rekwizycyjnych, względnie należności z tytułu uskutecznionych świadczeń wojennych miało następować pod rygorem utraty pretensji

Spraw Wewnętrznych na wniosek Ministra Spraw Wojskowych zostaje upoważniony do przekazywania na obszarach zagrożonych władzy wykonawczej w przedmiocie zabezpieczenia i utrzymania porządku i spokoju publicznego oraz do wydawania nakazów i zakazów, zmierzających do utrzymania bezpieczeństwa państwa i wojska dowódcom wojskowym, przy czym wyłącznie Rada Ministrów posiadała uprawnienie do uchylenia rozporządzenia Ministra Spraw Wojskowych o przekazaniu władzy wykonawczej dowódcom wojskowym, zob. rozporządzenie Rady Obrony Państwa z dnia 15 lipca 1920 r. o wydawaniu bezpośrednich nakazów rekwizycyjnych przez władze wojskowe (uzupełnienie ustawy z dnia 28 października 1919 r.), Dz. U. z 1920 r. Nr 62, poz. 407; rozporządzenie Rady Obrony Państwa z dnia 20 lipca 1920 r. w przedmiocie pociągania ludności do osobistych i rzeczowych świadczeń przy akcji ewakuacyjnej, Dz. U. z 1920 r. Nr 64, poz. 425; rozporządzenie Rady Obrony Państwa z dnia 20 lipca 1920 r. w przedmiocie upoważnienia Ministra Spraw Wewnętrznych do częściowego przekazania władzy wykonawczej władzom wojskowym, Dz. U. z 1920 r. Nr 64, poz. 427; przepisy wykonawcze Ministra Spraw Wewnętrznych z dnia 4 sierpnia 1920 r. do rozporządzenia Rady Obrony Państwa z dnia 20 lipca $1920 \mathrm{r}$. w przedmiocie pociągania ludności do osobistych i rzeczowych świadczeń przy akcji ewakuacyjnej, Dz. U. z 1920 r. Nr 71, poz. 488. Na obszarach uznanych przez Ministerstwo Spraw Wojskowych za zagrożone pod względem wojennym, z chwilą przekazania na takich obszarach władzy wykonawczej Dowódcą Wojskowym mógł być mianowany gubernator wojskowy. Na temat szerokich kompetencji przysługujących gubernatorowi wojskowemu zob. rozporządzenie Rady Obrony Państwa z dnia 6 sierpnia 1920 r. w przedmiocie ustanowienia stanu oblężenia, Dz. U. z 1920 r. Nr 69, poz. 460. Szerzej na temat działalności prawodawczej Rady Obrony Państwa zob. P. Marszałek, Rada Obrony Państwa z 1920 roku. Studium prawnohistoryczne, Wrocław 1995, s. 116-142; tenże, Najwyższe władze wojskowe w systemie ustrojowym II Rzeczypospolitej, Wrocław 2011, s. 154-159.

28 Por. RDOKK Nr 76 z dnia 24 sierpnia 1920 r., poz. 909, s. 4, który stanowił, że do dnia rozpoczęcia rekwizycji (siana i słomy) zakupy tych produktów były dozwolone po cenach rynkowych.

29 Zob. DRMSW Nr 58 z dnia 20 maja 1919 r., poz. 1855; RDOGK Nr 104 z dnia 14 października 1920 r., poz. 10, s. 3; Wzór kwitu rekwizycyjnego, DRMSW Nr 48 z dnia 21 grudnia 1920 r., poz. 1002.

30 Por. RDOKK Nr 102 z dnia 10 października 1920 r. w sprawie realizacji kwitów rekwizycyjnych, poz. 22, s. 9 .

31 Na temat wypłaty rekwizycji pokrytych kwitami nieformalnymi zob. Wypłata rekwizycji pokrytych kwitami nieformalnymi, DRMSW Nr 40 z dnia 3 listopada 1920 r., poz. 868. 
w ciągu 6 miesięcy od dnia ustania powszechnego obowiązku do świadczeń wojennych. W razie gdy władze wojskowe, względnie oddziały wojskowe nie mogły pokryć swego zapotrzebowania w drodze kupna $z$ wolnej ręki lub najmu, to posiadały możliwość zwrócenia się do władz administracyjnych o wydanie polecenia ludności dostarczenia potrzebnych przedmiotów ${ }^{32}$.

Właściciel przedmiotów świadczenia wojennego, który nie otrzymał zapłaty za swoje świadczenia lub z jakiegokolwiek powodu czuł się pokrzywdzony, posiadał prawo zażalenia w terminie miesięcznym do Okręgowej Komisji Rekwizycyjnej (OKR) przy Dowództwie Okręgu Wojskowego, zaś od tej ostatniej decyzji służyło również w terminie miesięcznym prawo odwołania się do Głównej Komisji Rekwizycyjnej (GRK) przy Ministerstwie Spraw Wojskowych ${ }^{33}$. Komisje te, wraz z działającymi na szczeblu powiatu (miasta) komisjami świadczeń wojennych ${ }^{34}$, stanowiły kolegialne organy, których celem była pomoc w egzekwowaniu świadczeń lub rozstrzyganie spornych kwestii wynikających z egzekwowania ${ }^{35}$.

Dodajmy, że wobec masowych nadużyć wojska w postaci licznych rabunków, plądrowania i bezprawnych rekwizycji zarówno w czasie działań zbrojnych, ale przede wszystkim już po ich zakończeniu, wszystkie władze wojskowe i cywilne zostały obowiązane wszelkie doniesienia ludności cywilnej lub organów władzy

32 Władze i organy uprawnione do żądania świadczeń wojennych, podmioty na które świadczenia wojenne miały być nakładane, określenie miejsc, terminu i sposobu dostarczenia świadczeń oraz zagadnienia przekroczenia uprawnień zostały określone w rozporządzeniu wykonawczym Ministra Spraw Wojskowych i Ministra Spraw Wewnętrznych do Ustawy z dnia 11 kwietnia 1919 r., o rzeczowych świadczeniach wojennych, Dziennik Praw (dalej: Dz. Pr.) z 1919 r. Nr 32, poz. 264 . Z czasów wojny polsko-bolszewickiej w 1920 r. znane są przykłady dostarczania środków transportowych w postaci koni, a przypadki odmowy dostarczania ich były nieliczne, zob. R. Juszkiewicz, Działania militarne na Mazowszu pólnocnym i w korytarzu pomorskim. 1920 rok, Warszawa 1997, s. 276-277. Por. Pobieranie koni przez Oddziały wojsk, DRMSW Nr 48 z dnia 21 grudnia 1920 r., poz. 995.

33 Rozporządzenie wykonawcze Ministra Spraw Wojskowych i Ministra Spraw Wewnętrznych z dnia 12 grudnia 1919 r. do art. 10 ust. 3, art. 11 i 12 Ustawy z dnia 11 kwietnia 1919 r., o rzeczowych świadczeniach wojennych, w przedmiocie utworzenia Komisji Rekwizycyjnych Okręgowych i Głównej, Dz. U. z 1920 r. Nr 97, poz. 514. Regulamin Okręgowych Komisji Rewizyjnych i Głównej Komisji Rewizyjnej uregulowano 1 października 1920 r., zob. rozporządzenie Ministra Spraw Wojskowych i Ministra Spraw Wewnętrznych w przedmiocie regulaminu Okręgowych i Głównej Komisji Rekwizycyjnych, M.P. z 1920 r. Nr 270. Por. Z. Zdziechowski, O zaskarżalności orzeczeń Głównej Komisji Rekwizycyjnej przy M. S. Wojsk., Wojskowy Przegląd Prawniczy 1928, nr 2, s. 22-25.

34 Zagadnienia powoływania i wynagrodzenia członków komisji powiatowych (miejskich) regulowało rozporządzenie Ministerstwa Spraw Wojskowych i Ministerstwa Spraw Wewnętrznych z dnia 17 maja 1919 r. w sprawie Powiatowych Komisji świadczeń wojennych, M.P. z 1919 r. Nr 118.

35 Szerzej na temat problemów praktyki rekwizycyjnej oraz działalności komisji rekwizycyjnych po zakończeniu wojny, a także zaskarżeń orzeczeń Głównej Komisji Rekwizycyjnej do Najwyższego Trybunału Administracyjnego zob. A. Podolska-Meducka, Od wojny do wojny. System świadczeń wojennych w Polsce w latach 1918-1921, Warszawa 2011, s. 324-388. 
dotyczące tych czynów przestępnych podawać do wiadomości bezpłatnie i z możliwym przyśpieszeniem do najbliższego dowództwa dywizji, względnie okręgu etapowego, zaś poza obszarem wojennym dowództwa okręgu generalnego lub rejonu wojskowego ${ }^{36}$. Sytuacje nadużyć ze strony wojska stanowiły zatem poważny problem, który najwyższe władze wojskowe starały się ograniczać drogą dyscyplinowania żołnierzy za pomocą rozkazów wojskowych.

\section{Orzecznictwo Najwyższego Trybunału Administracyjnego w sprawach rekwizycji}

Po dokonaniu analizy obowiązującego w interesującym nas przedziale czasu ustawodawstwa rekwizycyjnego należy odnieść się, celem jej dopełnienia, jeszcze do orzecznictwa sądowego w tym zakresie, a w szczególności do orzecznictwa sądów administracyjnych ${ }^{37}$.

Sądownictwo administracyjne - obejmujące urządzenia prawne, które zabezpieczają jednostkę przeciwko nadużyciom władz administracyjnych, a więc również nadużyciom rekwizycyjnym, stanowiącym władczy akt jednostronny o charakterze administracyjnym ${ }^{38}$ - na kontynencie europejskim ${ }^{39}$ pojawiło się w okresie rewolucji francuskiej ${ }^{40}$ i z Francji instytucja ta „przeszła do innych państw, które

36 Rozporządzenie Ministrów Spraw Wojskowych, Spraw Wewnętrznych, Poczt i Telegrafów i Kolei z dnia 23 października 1920 r. w przedmiocie ułatwienia donoszeń ludności cywilnej, odnoszących się do bezprawnych rekwizycji i plądrowania przez osoby wojskowe, Dz. U. z 1920 r. Nr 98, poz. 658.

37 Szerzej na temat orzecznictwa Sądu Najwyższego w tych sprawach zob. orzeczenia SN: z dnia 13 czerwca 1919 r., 11/19; z dnia 4 listopada 1920 r., 349/1920; z dnia 8 kwietnia 1922 r., C 1027/21; z dnia 26 października 1922 r., I C 201/22; z dnia 18 maja 1923 r., C 63/23; z dnia 3 marca 1924 r., I C 267/23; z dnia 10 marca 1924 r., I C 957/23 oraz wyrok SN z dnia 19 grudnia 1924 r., C 339/24. Na temat odszkodowań za świadczenia wojenne z okresu I wojny światowej zob. m.in. Archiwum Państwowe w Poznaniu (APP), Urząd Wojewódzki Poznański, Sprawy budżetowo-finansowe, „Świadczenia wojenne powiatu kępińskiego” i „Świadczenia wojenne powiatu obornickiego”, zespół nr 296, sygn. 152 (k. 1-133) i 153 (k. 1-72).

38 Zob. W.L. Jaworski, Nauka prawa administracyjnego. Zagadnienia ogólne, Warszawa 1924, s. 14. Por. W. Chróścielewski, Akt administracyjny generalny, Łódź 1994, s. 83-98.

39 Por. I. Dyrda, Podstawowe cechy nauki angielskiego prawa administracyjnego, Wrocław 1979, s. 149-169; P. Przybysz, Modele sadowej kontroli administracji w państwach członkowskich Unii Europejskiej, Administracja. Teoria - Dydaktyka - Praktyka 2007, nr 1, s. 38-56.

40 Rewolucja francuska, odwołując się do wartości prądów umysłowych okresu Oświecenia, stworzyła podwaliny pod nowożytny system prawa administracyjnego, który wyrósł z przekonania o wyższości państwa prawnego (rozumianego jako związanie prawem działalności administracyjnej państwa) nad modelem państwa o charakterze jednolitej władzy struktury państwowej, uzależnionej wyłącznie od 
ją przyjęły w mniej lub więcej wyrobionym już stanie" ${ }^{\prime 1}$. Celem tego rodzaju wymiaru sprawiedliwości było „dążenie do poddania administracyjnej działalności państwa prawu, które by wiązało dwustronnie - państwo i obywatela - i które by urzeczywistniało zasadę równości wszystkich wobec prawa oraz dawało gwarancję prawom obywatelskim" ${ }^{\prime 2}$. Oznacza to, że właściwą realizację ochrony praw jednostki zapewniać miała odtąd sądowa kontrola administracji1 ${ }^{43}$, której główny punkt ciężkości istnienia spoczywał na publicznym prawie podmiotowym ${ }^{44}$.

W Polsce sądownictwo administracyjne pojawiło się wraz z powołaniem do życia Księstwa Warszawskiego ${ }^{45}$, w którym wzorem dla organizacji administracji państwowej była oczywiście napoleońska Francja ${ }^{46}$. Po odzyskaniu przez Polskę

monarchy, zob. J. Filipek, Rola prawa w działalności administracyjnej państwa, Zeszyty Naukowe Uniwersytetu Jagiellońskiego. Prace Prawnicze 1974, z. 65, s. 13-14; M. Konarski, Jakość wartości sądowej kontroli administracji publicznej, w: Problemy z sadowa ochrona praw człowieka, t. 1, red. R. Sztychmiler, J. Krzywkowska, Olsztyn 2012, s. 517-518.

41 W.L. Jaworski, Nauka prawa..., s. 42.

42 M. Sczaniecki, Powszechna historia państwa i prawa, Warszawa 1994, s. 396. Por. K. Sójka-Zielińska, Drogi i bezdroża prawa. Szkice z dziejów kultury prawnej Europy, Wrocław 2010, s. 145-154; M. Konarski, Prawo i rewolucja: Rozważania jurysty o rewolucji francuskiej 1789-1794, Studia Prawnicze i Administracyjne 2016, nr 15 (1), s. 31-47.

43 Por. R. Suwaj, Sądowa kontrola działań administracji publicznej jako przejaw judycjalizacji postępowania administracyjnego, Studia Prawnoustrojowe 2009, nr 9, s. 200-201.

44 Zob. J.S. Langrod, Zarys sądownictwa administracyjnego ze szczególnym uwzględnieniem sądownictwa administracyjnego w Polsce, Warszawa 1925, s. 26. Por. A. Wróbel, Prawo podmiotowe publiczne, w: System Prawa Administracyjnego, t. 1. Instytucje prawa administracyjnego, red. R. Hauser, Z. Niewiadomski, A. Wróbel, Warszawa 2010, s. 305-358 i przywołaną tam literaturę.

45 A. Kubiak-Kozłowska w podręczniku Polskie sądownictwo administracyjne, pod redakcją Z. Kmieciaka, upatruje genezy sądownictwa administracyjnego na ziemiach polskich już w czasach demokracji szlacheckiej, a Trybunał Radomski postrzega autorka jako pierwszy polski sąd administracyjny ze względu na kompetencję do rozpoznawania sporów administracyjnych w procedurze sądowej, zob. taż, Ewolucja i ustrój sądownictwa administracyjnego w Polsce, w: Polskie sądownictwo administracyjne, red. Z. Kmieciak, Warszawa 2006, s. 29 i nn.

46 Zob. W. Witkowski, Sadownictwo administracyjne w Księstwie Warszawskim i Królestwie Polskim 1807-1867, Warszawa 1984, s. 13; M. Krzymkowski, Rada Stanu Księstwa Warszawskiego, Poznań 2011, s. 197; P. Cichoń, Wplywy francuskie w administracji Księstwa Warszawskiego, Prace Historyczne 2013, t. 140, nr 1, s. 1-18. Z kolei C. Martysz genezę sądownictwa administracyjnego we Francji upatruje już w czasach przed rewolucją francuską, zob. tenże, Sądownictwo administracyjne we Francji, Casus 1997, nr 6, s. 16-17. Na charakter sądowo-administracyjny Rady Królewskiej we Francji w XVI i XVII w. zwracał uwagę już J.S. Langrod, który wskazywał chociażby na rolę intendentów sprawujących rozliczne funkcje administracyjne w sprawach o rozkład i ściąganie podatków czy robót publicznych. Jednakże autor ten podkreślał, że dopiero ustawodawstwo roku 1789 likwidując specjalne sądy administracyjne we Francji, w tym Radę Królewską, dało podstawę rozwoju nowego ustroju sądownictwa administracyjnego w późniejszych latach, zob. tenże, Zarys sadownictwa administracyjnego..., s. 84-85. Por. J. Filipek, Rola prawa..., s. 17-20; A. de Tocqueville, Dawny ustrój i rewolucja, tłum. H. Szumańska-Grossowa, Warszawa 2009, s. 81-95 i 101-110; M. Konarski, Jakość wartości sqdowej kontroli..., s. 530; G. Smyk, Administrative Judiciary in the European Doctrine of Administrative 
niepodległości w 1918 r., wraz z przyjęciem Konstytucji marcowej w 1921 r. ${ }^{47}$ i powołaniem rok później do życia Najwyższego Trybunału Administracyjnego $(\mathrm{NTA})^{48}$, powstał autonomiczny i nowoczesny system sądowej kontroli administracji ${ }^{49}$, obejmujący swoją właściwością również orzecznictwo w sprawach rekwizycyjnych ${ }^{50}$.

W swojej przedwojennej historii orzeczniczej NTA wydał kilkanaście wyroków bezpośrednio dotyczących kwestii rekwizycji (do roku 1931 - później bowiem sprawy o tym charakterze nie były już przedmiotem skarg). Przez wzgląd na ramy niniejszych rozważań nie sposób ich wszystkich w tym miejscu poddać analizie, wobec czego wymienimy tylko kilka z nich, najbardziej w naszej ocenie interesujących dla przedmiotu badań.

Pierwszy w historii działalności orzeczniczej NTA wyrok w sprawie, której przedmiot stanowiły zagadnienia rekwizycji, zapadł w dniu 15 czerwca 1923 r. i dotyczył rekwizycji przedmiotów przez władze okupacyjne w okresie I wojny światowej $^{51}$. W świetle stanu faktycznego austriacka komenda etapowa zarekwirowała w 1916 r. różne przedmioty stanowiące urządzenia fabryki świec, będącej własnością skarżącej firmy, a dokonując rekwizycji wydała właścicielom firmy potwierdzenie zawierające opis i znamiona zarekwirowanych przedmiotów. Po wojnie przedmioty te znalazły się w posiadaniu polskich okręgowych zakładów mundurowych w miejscowości K. Po ich odnalezieniu strona skarżąca domagała się ich zwrotu, podnosząc, że owe przedmioty zostały jej bezprawnie odebrane, a strona nie otrzymała za nie żadnego wynagrodzenia. Szefostwo Intendentury okręgu korpusu nie uwzględniło tego żądania, powołując się na zasady prawa międzynarodowego, które stanowiły, że na obcym terytorium państwo prowadzące wojnę ma prawo

Law at the Turn of the 19th and 20th Centuries, Annales Universitatis Mariae Curie-Skłodowska. Sectio G. Ius 2018, t. 65, $\mathrm{nr}$ 1, s. 141-154.

47 Ustawa z dnia 17 marca 1921 r. - Konstytucja Rzeczypospolitej Polskiej, Dz. U. z 1921 r. Nr 44, poz. 267.

48 Ustawa z dnia 3 sierpnia 1922 r. o Najwyższym Trybunale Administracyjnym, Dz. U. z 1922 r. Nr 67, poz. 600. Szerzej na temat właściwości NTA zob. D. Malec, Najwyższy Trybunał Administracyjny 1922-1939 w świetle własnego orzecznictwa, Warszawa-Kraków 1999, s. 66-116.

49 Przypomnijmy, że sądownictwo administracyjne było zorganizowane inaczej na terenie trzech polskich województw zachodnich (śląskiego, poznańskiego i pomorskiego), gdzie cechowała je struktura trójinstancyjna, a inaczej w pozostałych województwach, w których jedyną instancją sądową był NTA, zob. W. Maisel, Wojewódzkie sądy administracyjne w Drugiej Rzeczypospolitej, Warszawa-Poznań 1976, s. 5-6 i nn.; A. Tarnowska, Sąownictwo administracyjne II RP a pruski model sądownictwa administracyjnego, Studia z Dziejów Państwa i Prawa Polskiego 2006, t. 9, nr 2, s. 415-444.

50 Por. B. Wasiutyński, Z powodu właściwości Najwyższego Trybunału Administracyjnego, Ruch Prawniczy, Ekonomiczny i Socjologiczny 1923, t. 3, z. 4, s. 575-593.

51 Zob. Zbiór Wyroków Najwyższego Trybunału Administracyjnego, t. 1, Warszawa 1923 (dalej: ZWNTA), Nr 92, 1. rej. 282/22, s. 206-208. 
rekwirowania przedmiotów jemu potrzebnych, zaś osoba pozbawiona w drodze rekwizycji przedmiotów ma wyłącznie prawo żądać odszkodowania od państwa rekwirującego, nigdy zaś zwrotu tych przedmiotów.

W maju 1922 r. Ministerstwo Spraw Wojskowych nie uwzględniło sprzeciwu firmy, co spowodowało wniesienie przez skarżącego skargi do NTA, w której domagał się uchylenia zaskarżonej decyzji, zarówno z powodu wadliwego postępowania, jak i z powodu naruszenia jego praw. Rozpatrując skargę, NTA zwrócił uwagę na brak kompetencji do jej rozstrzygnięcia, bowiem w jego ocenie sprawa dotyczyła rozstrzygnięcia sporu o własność rzeczy, względnie o kwestię, który z tytułów jako silniejszy wyklucza drugi słabszy. Wobec powyższego uznał, że zaskarżoną decyzję Ministra Spraw Wojskowych należy oceniać nie jako orzeczenie wchodzące w zakres administracji rządowej, ale oświadczenie jednej ze stron wiodących spór, zaś samą sprawę jako spór należący do właściwości sądów zwyczajnych, czego skutkiem było oddalenie skargi przez NTA jako nienadającej się do rozstrzygnięcia ${ }^{52}$.

W wyroku z dnia 12 lutego 1925 r. NTA potwierdził swoją właściwość do orzekania o legalności orzeczeń Głównej Komisji Rekwizycyjnej (GKR) wydanych na podstawie przepisów z lat 1919-1920 ${ }^{53}$. Przedmiotem postępowania była skarga obywatela Szczęsnego Traunfellera przeciwko GKR przy MSW z dnia 23 grudnia 1923 r. w zakresie wynagrodzenia za rekwizycję materiału budowlanego przez wojsko polskie, a w szczególności pretensji ze względu na spadek waluty. W uzasadnieniu NTA oddalił jednak tę skargę jako nieuzasadnioną, uznając, że Okręgowa Komisja Rewizyjna (OKR) przy Dowództwie Okręgu Generalnego Lwów ${ }^{54}$ przyznała już skarżącemu jako odszkodowanie za powyższą rekwizycję odpowiednią kwotę wynagrodzenia.

Kolejny wyrok NTA został wydany dnia 13 marca 1925 r. wskutek skargi obywatela Henocha Zimanda we Lwowie na orzeczenie GKR w Warszawie w sprawie rekwizycji cukru i świec przez wojsko polskie ${ }^{55}$. Co prawda strona skarżąca otrzymała wynagrodzenie za rekwizycję, co stwierdzono kwitem wydanym przez podchorążego M. pod datą 16 czerwca 1919 r., jednakże wniosła przeciw orzeczeniu Okręgowej Komisji (OK) odwołanie do GKR, w którym zaprzeczyła, by w danym wypadku w ogóle miała miejsce rekwizycja, i stwierdziła, że zabrane przez wojsko towary zostały u niego zakwestionowane wobec podejrzenia paskarstwa i powołując się w tym względzie na znajdujące się w aktach pismo podchorążego M. oraz na

\footnotetext{
52 Szerzej na temat badania właściwości przez NTA zob. D. Malec, Najwyższy Trybunał..., s. 116.

53 Zob. ZWNTA, t. 3 (1925), Nr 553, 1. rej. 332/24, s. 121-124.

54 Szerzej zob. A.A. Ostanek, Dowództwo Okręgu Generalnego „Lwów”, czyli o początkach terenowej administracji wojskowej w Małopolsce Wschodniej (1919-1921), Historia i Świat 2014, nr 3, s. 185-206. 
oświadczenie tegoż poddające $w$ wątpliwość fakt rekwizycji. GKR w drodze orzeczenia zatwierdziła decyzję OKR, zaznaczając, że fakt rekwizycji nastąpił w czerwcu 1919 r. Przeciw temu orzeczeniu skarżący wniósł do NTA skargę z wnioskiem o uchylenie orzeczenia z tego powodu, iż GKR nie rozpoznała zarzutów odwołania co do nielegalności zarządzonej rekwizycji. NTA przychylił się do skargi i uchylił zaskarżone orzeczenie z powodu wadliwego postępowania oraz zarządził zwrot skarżącemu złożonej kaucji.

W wyroku z dnia 16 kwietnia 1925 r. NTA rozpatrzył sprawę rekwizycji dla wojska przedmiotów z magazynów przedsiębiorcy zagranicznego ${ }^{56}$. W tym przypadku orzeczenie dotyczyło skargi związanej z rekwizycją dnia 1 grudnia 1920 r. na rzecz magazynu mundurowego Intendentury Okręgu Generalnego Warszawskiego (IOGW) ze składów skarżącej formy londyńskiej The Hellins Mill Co. Ltd., które znajdowały się w Warszawie przy ul. Świętokrzyskiej, 976 metrów tkaniny welwetowej. Intendentura tego Okręgu wystawiła poświadczenie wynagrodzenia odpowiedniej wysokości waluty polskiej na kwicie rekwizycyjnym, zaś strona skarżąca wniosła przeciw temu orzeczeniu zażalenie, twierdząc, że za towary pochodzenia zagranicznego, zarekwirowane u cudzoziemca, należy uiścić odszkodowanie w walucie obcej i przerachować ją na walutę polską według kursu obcej waluty w dniu uiszczenia tego zobowiązania. $Z$ tego powodu strona skarżąca zażądała uchylenia orzeczenia OKR i przyznania jej odszkodowania w funtach szterlingach, ewentualnie w markach polskich z różnicą kursu w dniu uiszczenia. NTA ostatecznie uznał skargę za nieuzasadnioną i orzekł, że dla ustalenia wysokości wynagrodzenia za zarekwirowane przedmioty miarodajnymi są jedynie przepisy ustawy o świadczeniach wojennych, a nie zasady prawa cywilnego, co więcej zaś, miarodajnym dla oznaczenia wartości i ceny przedmiotów zarekwirowanych na podstawie tej ustawy jest dzień rekwizycji tych przedmiotów.

W wyroku NTA z dnia 28 kwietnia 1925 r. sąd ten odniósł się do skargi, która dotyczyła rekwizycji trzech kas ogniotrwałych od lwowskiej firmy Emil Urich, za które zostało skarżącemu przyznane wynagrodzenie ${ }^{57}$. Jednakże strona skarżąca wniosła odwołanie, twierdząc, że w tym przypadku nie zaszła rekwizycja, bo kasy takie rekwizycji nie podlegały, i żądając albo zapłaty wartości tych kas według cen z roku 1922, albo zwrotu kas. Po zatwierdzeniu orzeczenia przez GKR strona skarżąca wniosła do NTA o uchylenie tego orzeczenia z powodu wadliwego postępowania i mylnej oceny sprawy pod względem faktycznym i prawnym. Skarżący twierdził bowiem, że komisje powinny kierować się zasadami procedury cywilnej,

56 Zob. tamże, Nr 621, 1. rej. 926/23, s. 296-299.

57 Zob. tamże, Nr 639, 1. rej. 1453/23, s. 345-347. 
a ponieważ rekwirowane przedmioty nie miały cen targowych, komisje winny były wypłacić wartość fakturową i uwzględnić dewaluację marki polskiej przy oznaczeniu ówczesnej wartości w koronach, zwłaszcza że kasy takie nie podpadały pod przepisy o świadczeniach wojennych, wobec czego należało kasy albo oddać, albo zapłacić ich pełną wartość. Sąd administracyjny nie podzielił powyższego stanowiska skarżącego, oddalając skargę, i stwierdził, że zarekwirowanie na potrzeby armii kas ogniotrwałych, co do których właściciel nie przytoczył żadnych danych, jakoby były mu niezbędne do zaspokojenia potrzeb osobistych lub wykonywania zawodu, jak i zatrzymanie tych kas na własność Państwa nie sprzeciwia się przepisom ustawowym.

W kolejnych latach, aż do 1931 r., sprawy dotyczące bezpośrednio lub pośrednio rekwizycji znajdowały swój finał jeszcze kilkukrotnie na wokandzie NTA. Przykładowo w wyroku z dnia 11 czerwca 1926 r. NTA zwrócił uwagę, że w wypadku rekwizycji nieruchomości na własność, która to nieruchomość znajduje się już w faktycznym władaniu władz wojskowych, wydanie kwitu rekwizycyjnego nie jest potrzebne $^{58}$. Z kolei w wyroku $\mathrm{z}$ dnia 18 października $1926 \mathrm{r}$. sąd ten zają się skomplikowanym problemem sposobu wymiaru zaległości powinności podwodowej ${ }^{59}$, stwierdzając m.in., że powinność podwodowa ani w ustawowym, ani potocznym znaczeniu nie może być uważana za źródło dochodowe gminy, lecz jedynie za sposób pokrycia kosztów świadczeń publicznych, wykonywanych przez gminę z tytułu jej publiczno-prawnego charakteru ${ }^{60}$. Natomiast w wyroku z dnia 27 marca 1931 r. $^{61}$ NTA odniósł się do definicji pojęcia "majątek państwowy” w kontekście obowiązku kwaterunku wojskowych i ważności umów zawartych przez byłe władze okupacyj$n e^{62}$, uznając, że pod tym wyrażeniem należy rozumieć majątek państwowy nieruchomy oraz wymienione w przywołanych przepisach ruchomości (przeważnie przynależności rzeczy nieruchomych).

58 Zob. ZWNTA, t. 4 (1926), Nr 982, 1. rej. 620/23, s. 433-435.

59 Zob. tamże, Nr 1017, 1. rej. 3586/25, s. 551-556. Szerzej na temat charakteru prawnego tej powinności zob. H. Konic, Samorząd gminny w Królestwie Polskim..., s. 185-188; W. Grabski, Ciężary samorzadu..., s. 14-23; M. Konarski, Przyczynek do badań..., s. 111-131; tenże, Publiczne posługi transportowe..., s. 113-135; tenże, Powinności podwodowe ..., s. 63-86.

60 Por. ustawę z dnia 11 sierpnia 1923 r. o tymczasowem uregulowaniu finansów komunalnych, Dz. U. z 1923 r. Nr 94, poz. 747.

61 Zob. ZWNTA, t. 9 (1931), Nr 373 A, 1. rej. 3156/29, s. 116-118.

62 Zob. dekret w przedmiocie umów, zawartych przez b. władze okupacyjne co do majątku publicznego, Dz. Pr. P. P. z 1919 r. Nr 5, poz. 99. 


\section{Zakończenie}

Podczas działań zbrojnych prowadzonych w wojnie polsko-bolszewickiej 1920 r., ale również po ich formalnym zakończeniu wojsko polskie nie ustrzegło się wielu nadużyć rekwizycyjnych wobec ludności cywilnej, czego owocem były liczne sprawy sądowe, które trafiały do organów wymiaru sprawiedliwości jeszcze wiele lat po zakończeniu wojny. Mimo szerzących się rabunków, plądrowania, samowolnych i bezprawnych rekwizycji szybka reakcja ze strony polskiego najwyższego dowództwa, dyscyplinującego poprzez system nakazów i kar te przestępcze zachowania ${ }^{63}$, pozwoliła chociaż $\mathrm{w}$ niewielkim zakresie zapobiec nielegalnym lub wadliwie przeprowadzanym rekwizycjom przez oddziały polskie.

Przywołajmy w tym miejscu fakt, że już w pierwszych dniach wojny polsko-bolszewickiej - 25 lutego 1920 r. Minister Spraw Wojskowych zwracał uwagę, że dowódcy niektórych oddziałów wojskowych przeprowadzają samowolnie rekwizycje koni będących prywatną własnością, wobec czego kategorycznie zabronił dokonywania takich rekwizycji na osobistą odpowiedzialność dowódców poszczególnych oddziałów ${ }^{64}$. Podobne, liczne uwagi zawierały wydawane

63 W świetle postanowień niemieckiego kodeksu karnego wojskowego z dnia 20 czerwca 1872 r., który został wprowadzony w odrodzonej Polsce ustawą z dnia 29 lipca 1919 r. o tymczasowym sądownictwie wojskowem (Dz. Pr. P. P. z 1919 r. Nr 65, poz. 389) i rozporządzeniem Rady Ministrów z dnia 10 maja 1920 r. w przedmiocie wprowadzenia w życie Wojskowego Kodeksu Karnego (Dz. U. z 1920 r. Nr 59, poz. 369), i obowiązywał do dnia 1 sierpnia 1928 r., „plądrowanie” należało do kategorii przestępstw przeciwko majątkowi. Przedmiotem tego przestępstwa była własność prywatna ludności, jednakże, jak zauważył W. Makowski, „zarazem jednak wchodzi w grę obowiązek wojskowy zachowania powagi wojska i porządku służbowego, stąd plądrowanie jest przestępstwem wojskowym, jakkolwiek posiada cechy wspólne $\mathrm{z}$ analogicznymi pospolitymi przestępstwami przeciw własności prywatnej", tenże, Kodeks karny wojskowy z dodaniem ustaw i przepisów wprowadczych, przechodnich i uzupetniajacych oraz komentarza, Warszawa 1921, s. 235. Kodeks ten w rozdziale VIII (\$127-136), w całości poświęconym „przestępstwom spełnionym polu na osobach lub mieniu”, penalizował zachowania związane ze swawolnym oddaleniem się z oddziału wojskowego w celu grabieży, lupienia rzeczy, plądrowania, niszczenia cudzych rzeczy w polu itp., zob. Niemiecki kodeks karny wojskowy $z$ dnia 20 czerwca 1872 r., według tłumaczenia Komisji Prawno-Wojskowej Tymczasowej Rady Stanu, Warszawa 1920, s. 33-35.

64 Por. rekwizycje koni w: APP, zespół nr 295, sygn. 197 (cały poszyt), 198 (cały poszyt), 199 (cały poszyt) i 651 (cały poszyt); RDOKK Nr 140 z dnia 31 grudnia 1920 r., poz. 18, s. 7; RDOKK Nr 24 z dnia 17 lutego 1920 r., poz. 28, 1. dz. 4476/X, s. 6, zabraniający rekwirowania wszelkich artykułów spożywczych przeznaczonych na wyżywienie w zakładach karnych; O zabronieniu samowolnej rekwizycji koni i innych przedmiotów, DRMSW Nr 21 z dnia 25 lutego 1919 r., poz. 698; RDOKK Nr 32 z dnia 8 kwietnia 1920 r., 1. dz. 1726/VIII, s. 14-16; Rekwizycje i odpowiedzialność za samowolne i bezprawne ich przeprowadzanie, DRMSW Nr 33 z dnia 14 września 1920 r., poz. 728. Por. RDOKK Nr 128 z dnia 5 grudnia 1920 r., poz. 11, s. 4-5; Zarządzenie, $w$ celu zwalczania szerzacych się nadużý ze strony żotnierzy, DRMSW $\mathrm{Nr} 37$ z dnia 12 października 1920 r., poz. 797; Zarzadzenie przeciw rabunkom, pladrowaniu i bezprawnym rekwizycjom, DRMSW Nr 37 z dnia 12 października 1920 r., poz. 798. 
w kolejnych miesiącach przez ministra rozkazy skierowane do oddziałów wojska polskiego, które dokonywały bezprawnego rekwirowania mienia ludności cywilnej ${ }^{65}$. Niestety, jeszcze miesiąc po podpisaniu rozejmu w Rydze (12 października 1920 r.) pomiędzy Polską a Rosją Sowiecką odnajdujemy rozkazy skierowane do dowódców oddziałów dokonujących samowolnych i bezprawnych rekwizycji, rabunków i plądrowania ${ }^{66}$.

Nie podlega dyskusji to, iż doświadczenia w zakresie egzekucji świadczeń w postaci rekwizycji mienia prywatnego, zdobyte przez polską administrację cywilną i wojskową w okresie kilku miesięcy konfliktu z bolszewicką Rosją, umożliwiły w następnych latach stworzenie nowego systemu świadczeń wojennych, który stojąc na gruncie konstytucyjnych zasad ówczesnej republiki, był często sprawdzany w ramach ćwiczeń mobilizacyjnych. Ujawniały się tym samym liczne niedostatki organizacyjne, które jednakże nie zostały ostatecznie wyeliminowane z polskiego systemu przygotowań wojennych do wybuchu II wojny światowej w $1939 \mathrm{r}$.

Podsumowując, można stwierdzić, że w poddanym analizie okresie instytucja rekwizycji była wykorzystywana zarówno $\mathrm{z}$ racji braków technicznych i zaopatrzeniowych wojska polskiego, jak i z powodu rozluźnienia dyscypliny wojskowej, szczególnie zaraz po zakończeniu działań zbrojnych. Te, szczególnie nielegalne rekwizycje doprowadzały często do ruiny majątkowej i tak już mocno spauperyzowane społeczeństwo polskie, nie zapisując się w historiografii administracji pochlebnie i nie przysparzając bynajmniej chwały orężu polskiemu. Wyłącznie późniejsze orzecznictwo Najwyższego Trybunału Administracyjnego w zakresie dokonanych rekwizycji i orzecznictwo Sądu Najwyższego w zakresie odszkodowawczym nie pozwalają na jednoznaczną negatywną ocenę działalności rekwizycyjnej prowadzonej przez wojsko polskie we wskazanym czasie.

65 Zakaz rekwizycji środków żywności przeznaczonych na potrzeby zakładów karnych i domów więziennych, DRMSW Nr 4 z dnia 17 lutego 1920 r., poz. 79; Zakaz rekwizycji inwentarza i koni w miejscowościach dotkniętych najazdem nieprzyjaciela oraz u uchodźców, DRMSW Nr 34 z dnia 21 września 1920 r., poz. 742; Zakaz rekwirowania benzyny i smarów w syndykatach rolniczych, DRMSW Nr 34 z dnia 21 września 1920 r., poz. 743; Rekwizycje samochodów, motocykli, rowerów i zapasowych części, DRMSW Nr 49 z dnia 28 grudnia 1920 r., poz. 1021. Por. RDOKK Nr 95 z dnia 27 września 1920 r., poz. 11, s. 5.

66 Ukrócenie nadużyć w stosunku do ludności cywilnej, DRMSW Nr 42 z dnia 16 listopada 1920 r., poz. 903; Postępowanie doraźne w wypadkach rabunków i plądrowania, DRMSW Nr 42 z dnia 16 listopada 1920 r., poz. 904. 


\section{Bibliografia}

Antonowicz L., Podręcznik prawa międzynarodowego, Warszawa 1993.

Babiński L., Rejestracja i indemnizacja strat wojennych $w$ świetle ustaw wydanych we Francji po r. 1814-15 i 1870-71, w Niemczech po r. 1870-71, w Austrji po r. 1866, w Rosji po r. 1904-5, w: Likwidacja skutków wojny $w$ dziedzinie stosunków prawnych i ekonomicznych $w$ Polsce, t. 2, Warszawa 1917.

Bardach J., Themis a Clio, czyli o potrzebie podejścia historycznego w prawoznawstwie, w: J. Bardach, Themis a Clio, czyli prawo a historia, Warszawa 2001.

Berman C., Mobilizacja w teorii i praktyce, Warszawa 1964.

Bierzanek R., Wojna a prawo międzynarodowe, Warszawa 1982.

Bierzanek R., Symonides J., Prawo międzynarodowe publiczne, Warszawa 2005.

Byers M., War Law. Understanding International Law and Armed Conflict, New York 2005.

Chróścielewski W., Akt administracyjny generalny, Łódź 1994.

Cichoń P., Wpływy francuskie $w$ administracji Księstwa Warszawskiego, Prace Historyczne 2013, t. 140, nr 1.

Clausewitz C. von, On War, tłum. J.J. Graham, Ware 1997.

Cybichowski Z., Międzynarodowe prawo wojenne, Lwów 1914.

Cybichowski Z., Polskie prawo państwowe na tle uwag z dziedziny nauki o państwie i porównawczego prawa państwowego, t. 3, Warszawa 1933.

Czekaj A., Obywatele czy kondotierzy? Postawy obywatelskie i moralne żotnierzy narodowego autoramentu wojsk Rzeczypospolitej w pierwszej połowie XVII wieku, w: Staropolska sztuka wojenna XVI-XVII wieku. Prace ofiarowane Profesorowi Jaremie Maciszewskiemu, red. I.M. Dacka-Górzyńska, A. Karpiński, M. Nagielski, Warszawa 2002.

Dembiński H., Wojna jako narzędzie prawa i przewrotu, Lublin 1936.

Dinstein I., The International Law of Belligerent Occupation, Cambridge 2019.

Dobosz P., Problemy metodologii wspótczesnej nauki prawa administracyjnego na tle metody historyczno-prawnej, Kwartalnik Prawa Publicznego 2001, nr 1.

Domański L., Przegląd przepisów prawnych, wydanych we Francji w związku $z$ wojna 1914-1915 roku (dokończenie), Gazeta Sądowa Warszawska 1915, nr 25 + dodatek.

Dyrda I., Podstawowe cechy nauki angielskiego prawa administracyjnego, Wrocław 1979.

Faszcza M.N., Kulturowe implikacje rzymskiej deditio w III-I wieku przed Chrystusem, w: Kapitulacje w dziejach wojen. Z dziejów wojskowości polskiej i powszechnej, red. A. Niewiński, Oświęcim 2017.

Filipek J., Rola prawa w działalności administracyjnej państwa, Zeszyty Naukowe Uniwersytetu Jagiellońskiego. Prace Prawnicze 1974, z. 65.

Filipiak Z., Kwaterunek wojskowy w domach prywatnych Księstwa Warszawskiego. Regulacje prawne, Studia Iuridica Toruniensia 2011, t. 9.

Gąsiorowska N., Rekwizycje w Księstwie Warszawskim okupowanym przez Rosję w roku 1813-15, w: Likwidacja skutków wojny w dziedzinie stosunków prawnych i ekonomicznych w Polsce, t. 2, Warszawa 1917.

Gilas J., Położenie prawnomiędzynarodowe Powiśla, Warmii i Mazur w latach 1918-1920, Komunikaty Mazursko-Warmińskie 1970, nr 2.

Grabski W., Ciężary samorządu w Królestwie Polskim, Warszawa 1908. 
Hart H.L.A., Pojęcie prawa, tłum. J. Woleński, Warszawa 1998.

Huchla A., Ciężary i świadczenia publiczne a podatki w świetle art. 84 Konstytucji Rzeczypospolitej Polskiej, w: Konstytucyjne uwarunkowania tworzenia i stosowania prawa finansowego i podatkowego, red. P.J. Lewkowicz, J. Stankiewicz, Białystok 2010.

Iwaszkiewicz J., Rejestracja i indemnizacja strat wojennych na Litwie po roku 1812, w: Likwidacja skutków wojny $w$ dziedzinie stosunków prawnych i ekonomicznych $w$ Polsce, t. 2, Warszawa 1917.

Jaworski E., "Military Necessity” and „Civilian Immunity”: Where is the Balance, Chinese Journal of International Law 2003, t. 2, nr 1.

Jaworski W.L., Nauka prawa administracyjnego. Zagadnienia ogólne, Warszawa 1924.

Juszkiewicz R., Działania militarne na Mazowszu pótnocnym $i$ w korytarzu pomorskim. 1920 rok, Warszawa 1997.

Kasznica S., Polskie prawo administracyjne. Pojęcia i instytucje zasadnicze, Poznań 1946.

Koch M., Wojskowa ekonomika zaopatrzenia materiałowo-technicznego, Warszawa 1980.

Konarski M., Godność osoby ludzkiej a wojna lądowa $w$ świetle prawa międzynarodowego, w: Normatywny wymiar godności człowieka, red. W. Lis, A. Balicki, Lublin 2012.

Konarski M., Jakość wartości sądowej kontroli administracji publicznej, w: Problemy z sądowa ochrona praw człowieka, t. 1, red. R. Sztychmiler, J. Krzywkowska, Olsztyn 2012.

Konarski M., Legal Aspects of Organising the Administration of Food for the Army in the Duchy of Warsaw between 1807 and 1812, Biuletyn Stowarzyszenia Absolwentów i Przyjaciół Wydziału Prawa Katolickiego Uniwersytetu Lubelskiego 2020, t. 25, nr 1.

Konarski M., Powinności podwodowe w świetle przekazu pierwszych sześciu tomów „Volumina Legum", Biuletyn Stowarzyszenia Absolwentów i Przyjaciół Wydziału Prawa Katolickiego Uniwersytetu Lubelskiego 2019, t. 14, nr 2.

Konarski M., Prawo i rewolucja: Rozważania jurysty o rewolucji francuskiej 1789-1794, Studia Prawnicze i Administracyjne 2016, nr 1 (15).

Konarski M., Przyczynek do badań nad publicznymi posługami transportowymi i komunikacyjnymi w dawnym prawie polskim, Studia Prawnicze KUL 2019, nr 3.

Konarski M., Publiczne posługi transportowe $w$ okresie Księstwa Warszawskiego $w$ świetle postanowień dekretu $z$ dnia 22 maja 1810 roku „względem koni i podwód dostarczonych pod transporty i wojskowych", Czasopismo Prawno-Historyczne 2019, nr 2.

Konic H., Samorząd gminny w Królestwie Polskiem w porównaniu z innemi krajami europejskiemi, Warszawa 1906.

Kraushar A., Sprawa likwidacji strat wojennych za Księstwa Warszawskiego (1807-15), $\mathrm{w}$ : Likwidacja skutków wojny $w$ dziedzinie stosunków prawnych i ekonomicznych $w$ Polsce, t. 2, Warszawa 1917.

Krzymkowski M., Rada Stanu Księstwa Warszawskiego, Poznań 2011.

Kubiak-Kozłowska A., Ewolucja i ustrój sądownictwa administracyjnego w Polsce, w: Polskie sądownictwo administracyjne, red. Z. Kmieciak, Warszawa 2006.

Langrod J.S., Zarys sądownictwa administracyjnego ze szczególnym uwzględnieniem sądownictwa administracyjnego w Polsce, Warszawa 1925.

Lewy M., Uwagi w kwestji szacowania wynagrodzenia za rekwizycje, dokonane przez Niemców w b. Królestwie Polskiem, Warszawa 1920.

Luban D., Military Necessity and the Cultures of Military Law, Leiden Journal of International Law 2013, t. 26, nr 2. 
Łopatecki K., Zawłaszczenie nieruchomości na przykładzie działań wojennych z początku XVII wieku w Rzeczypospolitej Obojga Narodów. Z badań nad prawem zdobyczy wojennej w epoce nowożytnej, Zeszyty Prawnicze 2016, t. 16, nr 4.

Łyskowski I., O metodzie w badaniach prawno-historycznych, Ruch Prawniczy, Ekonomiczny i Socjologiczny 1929, t. 9, z. 1.

Maisel W., Wojewódzkie sq̨dy administracyjne w Drugiej Rzeczypospolitej, Warszawa-Poznań 1976.

Makowski J.E., Prawo międzynarodowe, Warszawa-Lublin 1918.

Makowski W., Kodeks karny wojskowy z dodaniem ustaw i przepisów wprowadczych, przechodnich i uzupetniających oraz komentarza, Warszawa 1921.

Malec D., Najwyższy Trybunał Administracyjny 1922-1939 w świetle własnego orzecznictwa, Warszawa-Kraków 1999.

Marszałek P., Najwyższe władze wojskowe w systemie ustrojowym II Rzeczypospolitej, Wrocław 2011.

Marszałek P., Rada Obrony Państwa z 1920 roku. Studium prawnohistoryczne, Wrocław 1995.

Martysz C., Sadownictwo administracyjne we Francji, Casus 1997, nr 6.

Orzechowski J., Dowodzenie i sztaby. II wojna światowa i współczesność, Warszawa 1986.

Ostanek A.A., Dowództwo Okręgu Generalnego „Lwów”, czyli o początkach terenowej administracji wojskowej w Małopolsce Wschodniej (1919-1921), Historia i Świat 2014, nr 3.

Podolska-Meducka A., Od wojny do wojny. System świadczeń wojennych w Polsce w latach 1918-1921, Warszawa 2011.

Popper K.R., Logika odkrycia naukowego, tłum. U. Niklas, Warszawa 1977.

Przeniosło M., Ziemiaństwo w Królestwie Polskim i jego straty poniesione w pierwszym roku Wielkiej Wojny, Dzieje Najnowsze 2004, nr 3.

Przybysz P., Modele sądowej kontroli administracji w państwach członkowskich Unii Europejskiej, Administracja. Teoria - Dydaktyka - Praktyka 2007, nr 1.

Przygodzki J., Rekwizycje w Księstwie Warszawskim w okresie rosyjskich rządów okupacyjnych, Acta Universitatis Wratislaviensis. Prawo 2001, nr 273.

Rundstein S., Szkody wojenne. Teoria nadzwyczajnych indemnizacji w prawie publicznym, Warszawa 1916.

Sczaniecki M., Powszechna historia państwa i prawa, Warszawa 1994.

Skrzypek W., Rozkaz wojskowy a decyzja administracyjna, Wojskowy Przegląd Prawniczy 2020, nr 1 .

Skubiszewski K., Prawo wojny i neutralności w świecie współczesnym, Ruch Prawniczy, Ekonomiczny i Socjologiczny 1967, t. 29, z. 1.

Smolka F., Ptolemejska ustawa kwaterunkowa, Archiwum Towarzystwa Naukowego we Lwowie. Wydział 2, Historyczno-Filozoficzny 1935, t. 16, z. 3.

Smyk G., Administrative Judiciary in the European Doctrine of Administrative Law at the Turn of the 19th and 20th Centuries, Annales Universitatis Mariae Curie-Skłodowska. Sectio G. Ius 2018, t. 65, nr 1 .

Sójka-Zielińska K., Drogi i bezdroża prawa. Szkice z dziejów kultury prawnej Europy, Wroclaw 2010.

Srogosz T., Ekonomiczne i społeczne następstwa przemarszów oraz stacjonowania wojsk własnych na terenie województw łęczyckiego i sieradzkiego oraz ziemi wieluńskiej w XVII wieku, Acta Universitatis Lodziensis. Folia Historica 1990, t. 37. 
Stelmach J., Brożek B., Metody prawnicze, Kraków 2006.

Suwaj R., Sąowa kontrola działań administracji publicznej jako przejaw judycjalizacji postępowania administracyjnego, Studia Prawnoustrojowe 2009, nr 9.

Szalewska M., Ciężary i świadczenia publiczne, w: System Prawa Administracyjnego, t. 7. Prawo administracyjne materialne, red. R. Hauser, Z. Niewiadomski, A. Wróbel, Warszawa 2012.

Tarnowska A., Sadownictwo administracyjne II RP a pruski model sądownictwa administracyjnego, Studia z Dziejów Państwa i Prawa Polskiego 2006, t. 9, nr 2.

Tocqueville A. de, Dawny ustrój i rewolucja, tłum. H. Szumańska-Grossowa, Warszawa 2009.

Wagner K., „Potop” a wielka wojna pótnocna $w$ Warszawie w świetle rejestrów podatkowych przyczynek do porównania dwóch szwedzkich okupacji, Saeculum Christianum 2013, t. 20.

Wasiutyński, Z powodu właściwości Najwyższego Trybunału Administracyjnego, Ruch Prawniczy, Ekonomiczny i Socjologiczny 1923, t. 3, z. 4.

Wise M., Requisition During the French Revolution (1789-1815), Louisiana Law Review 1944, t. 6, nr 1.

Witkowski W., Sądownictwo administracyjne w Księstwie Warszawskim i Królestwie Polskim 1807-1867, Warszawa 1984.

Wróbel A., Prawo podmiotowe publiczne, w: System Prawa Administracyjnego, t. 1. Instytucje prawa administracyjnego, red. R. Hauser, Z. Niewiadomski, A. Wróbel, Warszawa 2010.

Zakrzewski T., Organizowanie sity zbrojnej w państwie, Warszawa 1938.

Zdziechowski Z., O zaskarżalności orzeczeń Głównej Komisji Rekwizycyjnej przy M. S. Wojsk., Wojskowy Przegląd Prawniczy 1928, nr 2.

Ziewiński J., Rozkaz wojskowy w prawie karnym, Warszawa 1986.

Ziewiński J., Z ogólnych rozważań nad istota i pojęciem rozkazu, Wojskowy Przegląd Prawniczy 1962, nr 3. 
